\title{
ОСОБЛИВОСТІ ВЗАЕМОДІЇ БАТЬКІВ 3 ДІТЬМИ, ЯКІ МАЮТЬ СИНДРОМ ДЕФІЦИТУ УВАГИ ТА ГІПЕРАКТИВНОСТІ
}

\author{
Наталія Гончаренко \\ аспірантка кафедри психології \\ Національний педагогічний університет імені М. П. Драгоманова \\ 01616, Україна, м. Київ, вул. Пирогова, 9 \\ практичний психолог \\ Дитяча клінічна лікарня №4 Солом’янського району м. Києва \\ 03680, Україна, м. Київ, просп. Комарова, 3 \\ n.a.honcharenko@gmail.com, http://orcid.org/0000-0001-5386-3772
}

\begin{abstract}
Анотація
У статті порушується актуальне питання особливостей взаємодії батьків і дітей, які мають діагноз СДУГ - синдром дефіциту уваги та гіперактивності. Зауважується, що, не зважаючи на поглиблення наукових знань про генетичні та нейропсихологічні механізми появи та розвитку синдрому, якісний рівень освіченості та навичок ефективної взаємодії батьків та педагогів 3 такими дітьми залишається досить низьким. На сьогодні синдром дефіциту уваги та гіперактивності $\epsilon$ визнаним медичною наукою захворюванням нейпропсихологічного етіогенезу, зумовленого складною комбінацією спадкового та соціально-психологічного чинників, жоден з яких не є необхідним або достатнім, щоб викликати розвиток СДУГ сам собою. Важливість адаптивного виховання дитини із СДУГ у сім'ї для оптимізації іiі розвитку та зниження ймовірності появи негативних симптомів, що супроводжують розлад, вважається очевидною.
\end{abstract}

Чинниками ризику появи у майбутньому в дітей із СДУГ таких несприятливих наслідків як токсикоманія, злочинність, агресивність, опозиційна поведінка є: материнська депресія, надмірна їхня директивність та вимогливість. Патологізуючими для дітей із СДУГ є умови структурної розмитості сім’ї, дифузність у прийнятті ролей, виховна невпевненість батьків, відсутність рефлексії виховної взаємодії.

На основі емпіричних даних доведено, що більш адекватні моделі взаємодії 3 дитиною властиві повним сім'ям, батькам та матерям більш зрілого віку, з вищою освітою. В таких сім'ях є більший відгук батьків на спільну роботу з психологічною службою у допомозі дитині адаптивно соціалізуватись і запобігти негативних наслідків розладу. Найбільше неефективних моделей - нетерплячості, зворотної агресії, покарань, відчаю, марних умовлянь - застосовують у взаємодії з дітьми молоді мами (які народили дітей до 18 років), деякі батьки. Найгірша ситуація з неконтрольованою поведінкою дитини вдома та в школі спостерігається у дисфункціональних сім'ях, де трапляються конфлікти, сварки, пияцтво батька, холодність, відстороненість матері, та тих, де обмежені житлові та матеріальні умови родини.

Зроблено висновок, що, хоча сімейне виховання само собою не може викликати появу симптомів СДУГ у дітей (за їх появу відповідають біологічні чинники), здатність батьків ефективно взаємодіяти з ними сприяє запобіганню розвитку проблемної опозиційної поведінки, адикцій у дітей в майбутньому. Просвіта щодо СДУГ та допомога батькам в опануванні ефективних виховних стратегій їхньої взаємодії з дітьми можуть компенсувати 
негативні згубні наслідки для дітей. Суттєвим чинником поліпшення структури сімейної взаємодії в системі «батьки-діти» може стати також психологічна та психіатрична допомога матерям, які мають власні проблеми, пов'язані із СДУГ (імпульсивність, нетерплячість, надмірна тривожність, схильність до депресії, емоційна неврівноваженість тощо), та високий рівень стресу.

Ключові слова: синдром дефіциту уваги та гіперактивності, розлади розвитку нервової системи, функції контролю, виконавчі функції, нейробіологічні механізми, взаємодія батьків і дітей.

\section{Вступ}

Сьогодні в Україні абревіатура СДУГ (англ. - ADHD) вже не потребує розшифрування не лише серед медичних та освітніх фахівців, а й серед пересічних громадян, яким у той чи інший спосіб доводиться стикатися з «незручною» поведінкою дітей або дорослих, що проявляється в імпульсивності, нетерплячості, надмірній рухливості, неконтрольованості емоцій та дій, неуважності, балакучості, незграбності, необов'язковості, труднощах планування, конфліктності, агресивності тощо. Згідно 3 даними сайту «Obozrevatel», в Україні до 7\% дітей мають діагноз СДУГ. Проте якісний рівень освіченості та навичок ефективної взаємодії батьків та педагогів з такими дітьми так і залишається досить низьким.

Синдрому дефіциту уваги та гіперактивності (СДУГ) присвячена численна кількість світових наукових досліджень у галузі медицини, медичної та педагогічної психології, корекційної педагогіки тощо, і пошуковий інтерес не вщухає через нові способи досліджень та оцінки цього явища. Нове осмислення та корегування отримують й діагностичні критерії розладу, представлені у міжнародних стандартах DSM (Діагностичне та статистичне керівництво з психічних розладів - нозологічна система США) та MКХ (Міжнародна класифікація хвороб). Останні версії DSM-V (2013) та MКХ11 (2018) вже змінили положення СДВГ з рубрик «поведінкових та емоційних розладів, що виникають у дитячому та підлітковому віці» на рубрики «розладів розвитку нервової системи». Ці кроки стали результатом накопичення безлічі нових наукових даних щодо нейробіологічних механізмів синдрому та його продовження у дорослому віці у разі відсутності своєчасної спеціалізованої допомоги та відповідних умов для розвитку такої дитини (Barkley, 1997, 2000, 2005; Tuckman, 2009; Willcutt, 2005; Solanto, 2002; Nigg, Stavro, Ettenhofer, Hambrick, Miller \& Henderson, 2005; Gizer, Waldman, Abramowitz, Barr, Feng, Wigg \& Rowe, 2008; Gozal \& Molfese, 2005 та ін.).

Наукові дані про СДУГ пов’язують його із запізнілим дозріванням лобових ділянок кори головного мозку, які відповідають за функцію контролю над поведінкою. Згідно 3 нейропсихологічною теорією (Barkley, 1997), СДУГ пояснюється гальмуванням чотирьох виконавчих нейропсихологічних функцій, а саме: робочої пам'яті, саморегуляції, інтерналізації мовлення та поведінкового контролю. Науковцем підкреслюється, що при СДУГ розвиток цих функцій не відповідає віку дитини, але за належного виховання вони можуть розвинутися у майбутньому до норми. Одним із проявів цього розладу $\epsilon$ гіперактивність як результат нездатності дитини до належного стримування своєї поведінки. У моториці це проявляється у надмірності руху, активності, у мові - в балакучості, у міжособистісній взаємодії - в нетерплячості, настирливості, у навчанні - в 
неорганізованості, непопосидючості тощо. Розумова імпульсивність позначається у швидкому прийнятті рішень, без обмірковування наслідків своїх вчинків. Звідси висока схильність до ризику дітей і підлітків із СДУГ. Невгамовність у рухах, моториці, нездатність всидіти на одному місці стають причиною найбільших труднощів у школі (Barkley, 2000, 2005).

Молекулярно-генетичні дослідження причин СДУГ дозволили науковцям об'єктивізувати роль спадковості СДУГ і виявити групу генів-кандидатів, пов'язаних із розладом (Willcutt, 2005). Візуальні дослідження мозку доводять ймовірність генетичної етіології СДУГ (Gizer, Waldman, Abramowitz, Barr, Feng, Wigg \& Rowe, 2008). Виявлені переконливі докази зв'язку між СДУГ та, зокрема, геном переносником допаміну DAT1 i геном рецептора допаміну DRD4. Причому DAT1 пов'язують 3 гіперактивноімпульсивними симптомами, а DRD4 з неуважними (Gizer, Waldman, Abramowitz, Barr, Feng, Wigg \& Rowe, 2008).

У дослідженнях Дж. Нігга, Дж. Ставро, М. Еттенхофера та ін. з'ясовано, що симптоми неуважності та дезорганізованості є результатом порушень роботи виконавчих функцій (наприклад, швидкості обробки інформації), тоді як симптоми гіперактивності/імпульсивності - функцій контролю (Nigg, Stavro, Ettenhofer, Hambrick, Miller \& Henderson, 2005). Тобто неуважність пов’язана з гальмуванням відгуку на стимул, а гіперактивність, навпаки, з високою швидкістю реакції.

Наявні наукові дані свідчать про те, що цей розлад спричинений поєднанням багатьох генетичних та екологічних факторів ризику, жоден з яких не $\epsilon$ необхідним або достатнім, щоб викликати розвиток СДУГ сам собою (Willcutt, 2005, 2010). До того ж вважається достатньо ймовірним, що різні взаємодії цих факторів ризику можуть як сприяти розвитку синдрому, так і пом'якшити ризики фенотипічних його проявів. Результати нещодавніх нейропсихологічних досліджень у групах близнюків та нерідних осіб чоловічої статі з використанням МРТ показали роль комбінації специфічних для СДУГ чинників і сімейних ефектів у впливі на виконавчі когнітивні функції лобнотім'яної ділянки мозку, так і не з'ясувавши домінантність лише одного з них (Godinez, Willcutt, Burgess, Depue, Andrews-Hanna \& Banich, 2015).

Отже, синдром дефіциту уваги та гіперактивності $є$ визнаним медичною наукою захворюванням нейпропсихологічного етіогенезу, що $\epsilon$ результатом складного комбінаторного впливу як спадкового чинника, так і соціально-екологічної атмосфери сім’ї, де виховується дитина на ранніх етапах іiі розвитку. Без належної терапевтичної допомоги дитині 3 діагнозом СДУГ в період дошкільного та молодшого шкільного дитинства з високим ступенем ймовірності симптоматика розладу буде представлена і в дорослому віці, що може несприятливо позначатися на долі людини. Своєчасна спеціалізована допомога сім'ям дітей із СДУГ, що спирається на сучасні дані про розлад, допоможе знизити ці негативні ризики.

Мета дослідження полягає в теоретичному узагальненні та аналізі емпіричних даних про особливості взаємодії батьків з дітьми, які мають діагноз СДУГ, і їх вплив на перебіг хвороби. Завдання дослідження: 1) проаналізувати питання особливостей взаємодії батьків і дітей, які мають діагноз СДУГ; 2) визначити, охарактеризувати та пояснити адекватні моделі взаємодії батьків з дитиною, у якої діагностовано СДУГ. 


\section{Методи дослідження}

У реалізації мети даної статті використано теоретичні методи дослідження (аналіз медичної та психологічної літератури; систематизація теоретичних даних); клінічні інтерв'ю, анкетування.

\section{Результати та дискусії}

Є загальновизнаним, що надмірна реактивність та проблеми саморегуляції, пов'язані зі СДУГ, проявляються вже на ранніх етапах життя дитини. I, хоча на сьогодні існує мало доказів специфічності цих характеристик для конкретних форм пізньої психопатології (через обмаль досліджень дорослої популяції), розповсюдженою є думка, що серед ранніх прогнозів їх походження є СДУГ (Nigg, Stavro, Ettenhofer, Hambrick, Miller \& Henderson, 2005). 3 огляду на це, важливість адаптивного виховання для оптимізації розвитку дитини із СДУГ є очевидною.

Огляд вітчизняних наукових публікацій, присвячених соціально-психологічному аспекту СДУГ, показав, що у якості «відправної точки» таких досліджень переважно є діти молодшого, рідше - підліткового віку, а на батьківські проблеми уваги звернено обмаль (Barkley, 2005; Заваденко, 2005; Корень \& Купріянова, 2015; Макарова \& Семакова, 2007; Романчук, 2015; Сухіна, 2018 та ін.). Водночас факт впливу сімейної ситуації та характеру взаємодії батьків з дітьми на розвиток СДУГ вимагає пильної уваги до цього питання, яке б не обмежувалося короткими порадами батькам, що треба, а чого не треба їм робити, виховуючи дітей.

Одна 3 головних функцій сім’ї - виховна. Сім’я була і залишається основним джерелом соціалізації дітей, місцем великих можливостей у формуванні їхньої особистості, особливо у перші дошкільні роки життя, коли формуються психічні процеси, емоції, характер, життєві установки. Виняткова роль у цьому процесі надається виховній діяльності батьків, їх взаємодії з дітьми.

У діяльнісній теорії спілкування під взаємодією розуміють його інтерактивну сторону, яка дозволяє не лише обмінюватись інформацією між суб'єктами спілкування, а й реалізувати деяку загальну для партнерів діяльність. У виховному процесі головною метою взаємодії $€$ розвиток особистостей сторін, їх взаємовідносин. Завдяки такій взаємодії успішно розвиваються здатність учасників спільної діяльності розуміти емоційні стани один одного, будувати свої дії 3 урахуванням дій партнера, готовність запропонувати свою допомогу, здатність до мирного розв'язання конфліктів тощо (Велитченко, 2005). Своєрідність спілкування між дорослим і дитиною надає цьому виду взаємодії певну специфіку. У процесі виховання дітей дошкільного, молодшого шкільного віку провідна роль у взаємодії надається дорослому, хоча і не є винятком зворотний вплив - дитини на вихователя (батька) (Бех, 2008), який, на жаль, залишається й досі мало вивченим.

На функцію соціалізації дитини із СДУГ у сім’ї впливає низка таких чинників, як: соціальне і матеріальне становище родини, рід занять та освіта батьків, їхній світогляд, цінності, морально-емоційна атмосфера в сім'ї тощо. Проте, як показують широкі дослідження цього питання у пострадянських країнах і за кордоном, умови соціалізації та розвитку дітей у сім'ях залишаються далекими не лише від ідеальних, але й достатніх. 
Згідно 3 даними сучасних вітчизняних досліджень, способи взаємодії батьків 3 дітьми, які мають гіперкінетичну, імпульсивну та/або неуважну симптоматику, досить варіативні і часто пов'язані 3 власними психологічними проблемами самих батьків (Брязгунов \& Касатікова, 2001; Макарова \& Семакова, 2007; Нодельсон, 2018; Романчук, 2015 та ін.). Наприклад, у дослідженні I. Макарової та Е. Семакової показано патологізуючу роль сім'ї для дітей із СДУГ в умовах структурної розмитості, дифузності у прийнятті ролей, виховній невпевненості батьків. Відсутність цілей, планування виховного процесу, знижена рефлексія батьків щодо своїх почуттів і поведінки не дозволяє вибудовувати каркас виховання у вигляді системи вимог, заборон, санкцій, які б задавали дитині орієнтири у діяльності. Виникає принцип замкненого кола: чим гірше дитина поводиться, тим більше виникає у батьків підстав для жорстких виховних проявів. Негативна проекція на дитину власних небажаних якостей згладжує невпевненість і почуття некомпетентності самих батьків (Семакова \& Макарова, 2007).

Особливостями функціонування сімей, де виховуються діти із СДУГ, зарубіжні дослідники послідовно називають високий ступінь негативізму, конфліктності, неблагополуччя, низький рівень ефективних методів виховання. Таким родинам властивий більш низький рівень задоволеності шлюбом, підвищений рівень батьківського стресу, більш високі показники депресії та інших типів психічних розладів (Anastopoulos, Sommer \& Schatz, 2009).

В одному 3 досліджень особливостей взаємодії батьків з дітьми у сім'ях, де виховуються діти з СЗУГ, та контрольних сім'ях, де відсутні такі проблеми (Johnston, 2007), було виявлено, що батьки у групах сімей із СДУГ використовували більше негативно-реактивних і менше позитивних стратегій виховання, ніж контрольні батьки. Причому безвідносно до ступеня інтенсивності розладу (сильного чи слабкого), материнське психологічне функціонування якісно відрізнялось між групами сімей iз СДУГ і сімей без проблем, але не між двома групами сімей із СДУГ. Серед батьків дітей із СДУГ був значно нижчим, ніж у контрольній групі сімей, показник самоповаги.

В іншому дослідженні предметом були діадні «матір-син», «батько-син» та тріадні «батько-матір-син» особливості взаємодії сімей з гіперактивними і нормальними синами віком від 6 до 12 років (Buhrmester, Camparo \& Christensen et al., 1992). Було з'ясовано, що у сім'ях з гіперактивними хлопчиками частіше траплявся примус, коли матері і сини взаємодіяли в діадичному варіанті. Ця репресія матері і сина переносилась у тріадний контекст, якщо батько демонстрував патерн поведінки «порятунок-примус». Таку тенденцію пов'язують із тим, що матері дітей шкільного віку більше часу проводять 3 ними передусім у якості сімейних керуючих, які відповідають за організацію, виконання обов'язків, накладених навчальним процесом, у той час як батьки витрачають більшу частину своєї взаємодії з дітьми на ігрові та спільні дії необов'язкового характеру. Одним із наслідків цього є те, що матері вимушено стають більш директивними і вимогливими, ніж батьки (Chen \& Johnston, 2005; Johnston \& Mash, 2001).

Було показано також, що опозиційно-зухвала поведінка дітей із СДУГ пов’язана 3 наявністю СДУГ у матерів (Zisser \& Eyberg, 2012).

Ці дослідження (Chronis, Lahey, Pelham, Williams, Baumann \& Kipp, 2007) засвідчили, що чинником ризику появи у майбутньому у дітей із СДУГ таких несприятливих наслідків як токсикоманія та злочинність, є материнська депресія. Цей 
факт був підтверджений на вибірці із 108 дітей, яким вперше був діагностований СДУГ у віці 4-7 років. Материнська депресія передбачала проблеми з поведінкою через 2-8 років після первісної оцінки, у той час як позитивне батьківське виховання викликало меншу кількість проблем з поведінкою у майбутньому.

Водночас, на жаль, значно менше є даних, які доводять позитивну роль адекватних виховних стратегій батьків на розвиток дитини із СДУГ. Так, у спостереженнях за 136 сім'ями хлопчиків 7-10 років 3 синдромом дефіциту уваги та гіперактивності було виявлено позитивний вплив на поведінку дітей чуйності і чутливості матері до дитини, іiі тепла і прийняття за наявності належного контролю (Johnston, Murray, Hinshaw, Pelham, Hoza, 2002). Материнська чуйність виявила унікальний негативний зв'язок з проблемами поведінки дитини, але не з симптомами СДУГ у дітей, і також була негативно пов'язана 3 депресивними симптомами у матері.

В нашій практиці роботи практичним психологом з батьками дітей із СДУГ (на базі Дитячої клінічної лікарні №4 Солом’янського району м. Києва) помічено, що матерям таких дітей властиві підвищена тривожність, емоційна неврівноваженість, схильність до покарань або байдужість, відстороненість, що викликані втомленістю, розгубленістю, безпорадністю справлятися 3 тиском дитячої активності, непосидючості, неорганізованості, з одного боку, а з іншого - шквалом нарікань на таку поведінку дитини з боку вчителів, вихователів, сусідів, просто перехожих на вулиці. Зрозуміло, що в таких станах ефективно взаємодіяти з дитиною досить важко, або взагалі не можливо.

Постановка дитині діагнозу СДУГ більшістю мам приймається 3 полегшенням («все стає на свої місця», «стало легше, що не одна я в усьому винна»). Батьки, навпаки, не відразу готові погодитись з каузальністю поведінки дитини, викликаною хворобою. Їм легше звинувачувати у розладах жінок, вихователів, вчителів, які «не можуть справитись і організувати дитину». Таку реакцію ми пояснюємо, зокрема, тим, що батьки значно меншу часу перебувають 3 дітьми. Повертаючись додому, проводять 3 ними короткий проміжок часу, переважно в ігровій, безтурботній діяльності (перегляд мультфільмів, фільмів, гра $з$ приставкою, комп’ютерні ігри, дитячі лото тощо). Мамам же дістається i більше часу, який вони проводять 3 дитиною, та більш відповідальні щоденні справи почистити зуби, поїсти, одягнутись, скласти речі, іграшки, прогулянка 3 дитиною і догляд за безпекою іiї поведінки (для самої дитини та для оточуючих). Для мам школярів таких справ стає ще більше.

Найчастіше по допомогу до психологічної служби лікарні звертаються батьки дітей із СДУГ від 6 до 9 років. Це періоди визначення готовності дитини до школи та безпосередньо важливий етап освоєння дитиною умінь навчатися. Як зазначають батьки (переважно мами), саме в цей час вони починають визнавати свою безпорадність та/або сором за нарікання з боку школи і вирішують звертатись по спеціалізовану допомогу.

Протягом кількох років нами проводилось інтерв'ювання та анкетування батьків, які мають дітей із СДУГ цього віку, де, окрім інших питань, визначались і способи їх взаємодії. Всього в опитуванні взяли участь 65 сімей (сім’ю представляв, зазвичай, один 3 батьків). Характеристика вибірки опитуваних така: 54 матері (з них 6 (11,1\%) - молодих матерів віком 24-28 років, $36(66,6 \%)$ - 29-40 років; 12 (22,2\%) - 41-52 роки); 11 батьків. 3 вищою освітою 44 особи $(67,6 \%)$, з середньою спеціальною - 21 (32,3\%). Повна сім'я - 41 $(63,0 \%)$, неповна сім'я - 24 (36,9\%); одна дитина в сім'ї - 38 (58,4\%), дві-три дитини - 27 
(41,5\%). Діти із СДУГ, батьки яких звертались за допомогою до психологічної служби, були усі хлопчиками від 6 до 9 років.

Питання ставились такі: «3 якими труднощами у поведінці Вашої дитини Ви найчастіше стикаєтесь?», «Як Ви з ними справляєтесь?», «Як Ви реагуєте на такі прояви у поведінці Вашої дитини, як: імпульсивність, непосидючість, неуважність, відволікання, конфлікти з Вами, конфлікти з оточуючими, агресія тощо?», «Яких навичок у взаємодії 3 дитиною Вам не вистачає?».

Аналіз відповідей батьків на перше питання не виявив суттєвої варіативності. Відповіді зводились до переліку класичних симптомів СДУГ, які найчастіше викликають нарікання батьків, вихователів, вчителів, та проявів опозиційної поведінки: «надмірна рухливість», «непосидючість», «протести», «негативізм», «агресія до оточуючих», «неслухняність», «неможливість домовитися», «істерики», «упертість», «неорганізованість», «невміння справлятись з емоціями», «нездатність зосередитися під час виконання домашніх завдань», «бійки з братом/сестрою» тощо.

Справляються з цими проявами батьки по-різному:

а) «терпляче переношу» - відповіли 15 батьків $(23 \%$ із загальної вибірки опитуваних), причому терплячість більш властива батькам - 54,5\% (від кількості опитаних чоловіків) і значно менше матерям - 14,8\% (від кількості опитаних жінок);

б) «злюсь, кричу» - такі стратегії взаємодії більше властиві матерям: 32 особи або 59,2\% від жіночої вибірки опитуваних, на відміну від 4 (36,3\%) з опитаних батьків;

в) «караю, соромлю, вимагаю припинити те, що мене дратує чи не влаштовує» - ця взаємодія більше виявилась притаманною батькам: 45,4\% чоловічої вибірки (5 осіб) та 37,0\% (20 осіб) - жіночої);

г) «плачу, впадаю у відчай» - зауважено лише матерями: 15 опитаних $(27,7 \%)$;

д) «намагаюсь домовлятися» - майже однаково використовуються як батьками, так і мамами дітей: 36,3\% (4 особи) батьків та 33,3\% (18 осіб) мам;

е) «умовляю змінити поведінку» - суто жіноча стратегія взаємодії: 61,1\% (33 особи) опитаних жінок обирають їі;

ж) «змінюю увагу на щось інше», «підкупляю чимось приємним», «мотивую заохоченням», «не звертаю уваги, набридло», «залишаю одного», «караю обох» (у сварках 3 братом), «жартую», «багато разів повторюю прохання поки не виконає», «жорстко контролюю» тощо - це поодинокі відповіді, які переважно належать мамам дітей.

Якісний аналіз анкетних даних та проведених клінічних інтерв'ю 3 батьками дозволив констатувати, що більш адекватні моделі взаємодії з дитиною властиві батькам та мамам більш зрілого віку з вищою освітою. В таких сім'ях ми зустріли і більший відгук батьків на їх сумісну роботу з психологічною службою щодо допомоги дитині адаптивно соціалізуватись і запобігти негативних наслідків розладу.

Найбільше неефективних моделей - нетерплячості, зворотної агресії, покарань, відчаю, марних умовлянь - застосовують у взаємодії з дітьми молоді мами (які народили дітей до 18 років), деякі батьки. Найгірша ситуація 3 неконтрольованою поведінкою дитини вдома та в школі спостерігалась у дисфункціональних сім'ях (конфлікти, сварки, пияцтво батька, холодність, відстороненість матері тощо) та тих, де житлові умови досить обмежені (наприклад, в однокімнатній квартирі проживають тато, мама та двоє дітей чи у двокімнатній квартирі бабуся, дідусь і мама з дитиною). У таких умовах дитина із СДУГ 
не в змозі перепочити, побути наодинці, заспокоїтись, а, навпаки, надто збуджена перебуванням у скупченні родичів, що погіршує ії стан.

У низці випадків мами пригадували своє власне дитинство і говорили, що були «такі ж непосидючі». Проте визнавати, що СДУГ у них також міг бути, відмовлялись, посилаючись лише на темперамент і що «усе з часом нормалізувалось».

Матері зауважили також, що легше справляються з проявами негативної поведінки, агресії, конфліктності, якщо це відбувається вдома, і значно фруструють у разі їх прояву у публічних місцях, школі, транспорті тощо, соромляться цих «викидів», часто відчувають злість, спрямовану або на дитину, або на себе, або на оточуючих. Деякі вказують, що погано себе контролюють у таких випадках, «зриваючись» на дітях.

Батьки усвідомлюють дефіцит таких власних якостей у взаємодії з дітьми, як: «терплячість», «послідовність», «наполегливість», «твердість характеру», причому в цьому питанні відмінностей між матерями та батьками практично не виявлено. Також батьки наголошують на потребі у більшій обізнаності щодо синдрому та спеціалізованій допомозі для дитини, відмовляючись у такій для себе особисто. Очевидно, що у нашій країні ще залишаються стійкими установки «не виносити сміття з хати», або «ми й самі розумні». Хоча, варто зазначити, така тенденція поступово змінюється.

Отже, взаємодія батьків та дітей із СДУГ має свої складності через специфічність розладу. Виховні впливи, що можуть ефективно застосовуватись зі здоровими дітьми, мотивувати їх, сприяти зміні поведінки та емоційних проявів, можуть стати марними, або, навіть, шкідливими під час взаємодії з дитиною із СДУГ. Навіть наше невеличке дослідження показує, що батькам властиво застосовувати неефективні методи взаємодії зі своїми особливими дітьми, не усвідомлюючи шкоди, яку вони наносять. А тому одним 3 перших кроків після того, як дитині поставлено діагноз СДУГ і визначено ступінь та особливості розладу, є підвищення компетентності батьків щодо самого розладу, усвідомлення ними корисності ефективних прийомів взаємодії з дитиною і марності тих, що не діють на неї. Наприклад, розповсюджений у вихованні спосіб переконання, умовляння дитини, який, до речі, дуже розповсюджений серед батьків, не працює для дитини із СДУГ: дитина не контролює своїх емоцій, послідовність дій чи обов'язковість не тому, що «вередує» чи не хоче, а тому, що не в змозі це робити через особливості роботи іiі мозку. I цей контроль батькам варто взяти на себе: підказати, нагадати, проконтролювати виконання і робити це у доброзичливій манері, можна в ігровій.

Отже, емпіричні дані засвідчують, що, хоча сімейне виховання само собою не може викликати появу симптомів СДУГ у дітей (за їх появу відповідають біологічні чинники), здатність батьків ефективно взаємодіяти з ними сприяє запобіганню розвитку проблемної опозиційної поведінки, адикцій у дітей в майбутньому. Просвіта щодо СДУГ та допомога батькам в опануванні ефективних виховних стратегій їхньої взаємодії з дітьми можуть компенсувати негативні згубні наслідки для дітей у майбутньому. Суттєвим чинником поліпшення структури сімейної взаємодії в системі «батьки-діти» може стати також психологічна та психіатрична допомога матерям, які мають власні проблеми, пов'язані із СДУГ (імпульсивність, нетерплячість, надмірна тривожність, схильність до депресії, емоційна неврівноваженість тощо) та високий рівень стресу. 
За нашими спостереженнями та згідно 3 даними вітчизняних та зарубіжних досліджень ефективними умовами взаємодії батьків з дітьми у разі діагнозу СДУГ можуть бути:

- толерантне ставлення як основа прийняття батьками дитини такою, якою вона є;

- чуйне виховання, що означає здатність батьків розуміти (зчитувати) і відповідно реагувати на репліки та поведінку дитини, здатність проявляти тепло, прийняття (Johnston, Murray, Hinshaw, Pelham \& Hozaand, 2002);

- здійснюваний контроль, який є твердим, послідовним i, одночасно, чутливим до потреб дитини, відсутність вседозволеності (Johnston, Murray, Hinshaw, Pelham \& Hoza, 2002; Johnston \& Jassy, 2007; Сухіна, 2018);

- підтримка самооцінки дитини на адекватному рівні - навіювання, підбадьорювання, підтримка впевненості дитини у собі, своїх досягненнях, перевагах;

- послідовне дотримання правил режиму дитини у сім’ї (Романчук, 2008; Сухіна, 2018);

- щоденна фізична активність, перебування на свіжому повітрі (Сухіна, 2018);

- наявність у дитини посильних для неї доручень, за допомогою яких організовується діяльність і стимулюються позитивні мотиви, створюються ситуації успіху тощо;

- позитивна соціальна взаємодія (навички комунікації, здатність батьків керувати власними емоційними станами, наявність системи заохочень, підтримки, жартівливість);

- впровадження у сім’ї ігрової діяльності (настільні ігри, ігри у слова, 3 предметами, спортивні);

- наявність тематичного спілкування - обговорення актуальних для дитини проблем, морально-етичних аспектів соціального життя опосередковано (прочитані історії, казки, фільми, мультфільми тощо);

- наявність гармонійних відносин між дорослими у родині (батько-мати, матибатько-бабусі-дідусі), відсутність травматичних переживань (розлучення батьків, сварки, конфлікти у сім'ї, алкогольна залежність батьків) тощо.

Методи умовлянь, заклики, загрози, залякування, агресивні покарання тощо, належать до найменш ефективних прийомів взаємодії з дитиною, яка має СДУГ.

\section{Висновки}

3 огляду на специфіку протікання процесу розвитку дитини із СДУГ, iї проблем в соціальній поведінці та навчанні, на виховні впливи та взаємодію батьків і дітей у сім’і варто звертати суттєву увагу. Вивчення ефективних прийомів взаємодії батьків з дитиною, яка має СДУГ, є суттєвою складовою розробки відповідних психокорекційних програм.

Впровадження системи психологічного супроводу сім’і, де виховується дитина 3 гіперактивним розладом та проблемами уваги, дозволить батькам змінити своє ставлення до особистості дитини, опанувати ефективні навички взаємодії з нею та стратегіями іiі розвитку, оптимізувати сімейну ситуацію, вирішити свої психологічні проблеми, що стримують гармонійні стосунки у родині.

Окрім зазначених, залишається актуальним питанням щодо того, як СДУГ розвивається в сім'ях, як родина та стосунки в ній посилюють або, навпаки, нівелюють негативну симптоматику СДУГ та розвиток супутніх розладів - конфліктності, 
опозиційно-зухвалої поведінки, депресивності, тривожності тощо. Перспективи подальших досліджень вбачаємо в розробці психокорекційних програм для дітей 3 діагнозом СДУГ.

\section{Література}

1. Бех, І.Д. (2008). Виховання особистості: підручник. Київ : Либідь.

2. Брязгунов, И.П., \& Касатикова Е.В. (2001). Непоседливый ребенок, или все о гиперактивных детях. Москва : Изд-во Ин-та психотерапии.

3. В Україні зростає кількість дітей 3 особливими потребами. Режим доступу: https://www.obozrevatel.com/ukr/health/mamaclub/v-ukraini-zrostae-kilkist-ditejz-osoblivimi-potrebami.htm

4. Велитченко, Л.К. (2005). Педагогічна взаємодія: теоретичні основи психологічного аналізу. Монографія. Одеса : ПНЦ АПН України.

5. Заваденко, Н.Н. (2005). Гиперактивность и дефиичит внимания в детском возрасте : учебное пособие. Москва : Академия.

6. Корень, Е.В., \& Куприянова, Т.А. (2015). Гиперкинетические расстройства. Москва. Режим доступа : https://docplayer.ru/28075910-Giperkineticheskie-rasstroystva-sdvgkoren-e-v-kupriyanova-t-a.html

7. Нодельсон, С.Е. (2018). СДВГ. Синдром дефициита внимания и гиперактивности. Семейная болезнь. Самара : Издательский Дом «Бахрах-М».

8. Романчук, О. (2015). Гіперактивний розлад з дефіцитом уваги у дітей. Львів : Свічадо.

9. Семакова, Е.В., \& Макарова, И.Ю. (2007). Семейно-социальные условия развития гиперактивности. Успехи современного естествознания, 9, 23-26. Режим доступна : http://www.natural-sciences.ru/ru/article/view?id=11467

10. Суковський, Є. (2008). Гіперактивний розлад з дефіциттом уваги у дітей: порадник для батьків. Львів : Колесо.

11. Сухіна, I.В. (2018). Гіперактивна дитина. Харків : Вид-во «Ранок», ВГ «Кенгуру».

12. Attention-Deficit/Hyperactivity Disorder. (2013). Diagnostic and Statistical Manual of Mental Disorders (DSM-5) (5 ed.). Arlington, VA: American Psychiatric Publishing. https://doi.org/10.1176/appi.books.9780890425596

13. Anastopoulos, A.D., Sommer, J.L., \& Schatz, N.K. (2009). ADHD and family functioning. Current Attention Disorders Reports, 1, 167-170. https://doi.org/10.1007/s12618-009$\underline{0023-2}$

14. Gozal, D. \& Molfese, D.L. (2005). (Ed.). Attention deficit hyperactivity disorder: from genes to patients. Totowa, New Jersey : Humana Press Inc.

15. Barkley, R.A. (2005). Attention-deficit hyperactivity disorder: A handbook for diagnosis and treatment (3rd. ed.). New York : Guilford Press.

16. Barkley, R.A. (1997). Behavioral Inhibition, Sustained Attention, and Executive Functions: Constructing a Unifying Theory of ADHD. Psychological Bulletin, 121(1), 65-94. https://doi.org/10.1037/0033-2909.121.1.65

17. Barkley, R.A. (2000). Genetics of Childhood Disorders: XVII. ADHD, Part 1: The Executive Functions and ADHD. Journal of the American Academy of Child and Adolescent Psychiatry, 39(8), 1064-1068. https://doi.org/10.1097/00004583-200008000-00025

18. Buhrmester, D., Camparo, L., Christensen, A., Gonzalez, L.S., \& Hinshaw, S.P. (1992). Mothers and fathers interacting in dyads and triads with normal and hyperactive sons. Developmental Psycholy, 28, 500-509. https://psycnet.apa.org/doi/10.1037/00121649.28.3.500

19. Chen, M., \& Johnston, C. (2007). Maternal inattention and impulsivity, and parenting behaviors. Journal of Clinical Child and Adolescent Psychology, Jul-Sep, 36(3), 455-468. https://doi.org/10.1080/15374410701448570. 
20. Chronis, A.M., Lahey, B.B., Pelham, W.E., Williams, S.H., Baumann, B.L., Kipp, H., et al. (2007). Maternal depression and early positive parenting predict future conduct problems in young children with attention-deficit/hyperactivity disorder. Developmental Psychology, 43, 70-82. https://doi.org/10.1037/0012-1649.43.1.70

21. Gizer, I.R., Waldman, I.D., Abramowitz, A., Barr, C.L., Feng, Y., Wigg, K.G., \& Rowe, D.C. (2008). Relations between multi-informant assessments of ADHD symptoms, DAT1, and DRD4. Journal of Abnormal Psychology, 117(4), 869-880. https://doi.org/10.1037/a0013297

22. Godinez, D.A., Willcutt, E.G., Burgess, G.C., Depue, B.E., Andrews-Hanna, J.R., \& Banich, M.T. (2015). Familial risk and ADHD-specific neural activity revealed by a case-control, discordant twin pair design. Psychiatry Research, 233, 458-465. https://dx.doi.org/10.1016\%2Fj.pscychresns.2015.07.019

23. ICD-11 for Mortality and Morbidity Statistics (Version: 04/2019). Retrieved from https://icd.who.int/browse11/1-m/en/\#/http://id.who.int/icd/entity/821852937

24. Johnston, C., \& Mash, E.J. (2001). Families of children with attention-deficit/hyperactivity disorder: Review and recommendations for future research. Clinical Child and Family Psychology Review, 4, 183-207. https://doi.org/10.1023/a:1017592030434

25. Johnston, C., Murray, C., Hinshaw, S.P., Pelham, W.E., \& Hoza, B. (2002). Responsiveness in interactions of mothers and sons with ADHD: Relations to maternal and child characteristics. Journal of Abnormal Child Psychology, 30(1), 77-88. https://doi.org/10.1023/a:1014235200174

26. Johnston, Ch. \& Jassy, J. (2007). Attention-Deficit/Hyperactivity Disorder and Oppositional/Conduct Problems: Links to Parent-Child Interactions. Journal of the Canadian Academy of Child and Adolescent Psychiatry, May, 16(2), 74-79. Retrieved from https://www.ncbi.nlm.nih.gov/pmc/articles/PMC2242643/

27. Nigg, J.T., Stavro, G., Ettenhofer, M., Hambrick, D.Z., Miller, T., \& Henderson, J.M. (2005). Executive Functions and ADHD in Adults: Evidence for Selective Effects on ADHD. Journal of Abnormal Psychology, Nov; 114(4), 706-717. https://doi.org/10.1037/0021$\underline{843 X .114 .3 .706}$

28. Solanto, M.V. (2002). Dopamine dysfunction in AD/HD: integrating clinical and basic neuroscience research. Behavioural Brain Research, Mar, 10; 130(1-2), 65-71. https://doi.org/10.1016/s0166-4328(01)00431-4

29. Tuckman, A. (2009). More Attention, Less Deficit: Success Strategies for Adults with ADHD. Plantation, Florida; Specialty Press.

30. Willcutt, E. (2005). The Etiology of ADHD: Behavioral and Molecular Genetic Approaches. Barch, D. (Ed.). Cognitive and Affective Neuroscience of Psychopathology. Oxford : Oxford University Press. Retrieved from https://pdfs.semanticscholar.org/3bb9/88b02a9829367286995a1fc837440bb4719f.pdf

31. Willcutt, E.G., Pennington, B.F., Duncan, L., Smith, S.D., Keenan, J.M., Wadsworth, S.J., DeFries, J.C., \& Olson, R.K. (2010). Understanding the complex etiologies of developmental disorders: behavioral and molecular genetic approaches. Journal of Developmental and Behavioral Pediatrics, 31(7), 533-544. https://doi.org/10.1097/DBP.0b013e3181ef42a1

32. Zisser, A.R. \& Eyberg, Sh.M. (2012). Maternal ADHD: Parent-Child Interactions and Relations With Child Disruptive Behavior. Child \& Family Behavior Therapy, 34(1), 33-52. Https://doi.org/10.1080/07317107.2012.654450

\section{References}

1. Bekh, I.D. (2008). Vykhovannia osobystosti: pidruchnyk [The education of the individual: a textbook]. Kiyv : Lybid [in Ukrainian] 
2. Bryazgunov, I.P., \& Kasatikova, E.V. (2001). Neposedlivyiy rebenok, ili vse o giperaktivnyih detyah [A casual baby, or all about hyperactive children]. Moscow : Izd-vo In-ta psihoterapii [in Russian].

3. V Ukrayini zrostaye kil'kist' ditey z osoblyvymy potrebamy [The number of children with special needs is increasing in Ukraine]. Retrieved from https://www.obozrevatel.com/ukr/health/mamaclub/v-ukraini-zrostae-kilkist-ditej-zosoblivimi-potrebami.htm [in Ukrainian]

4. Velytchenko, L.K. (2005). Pedahohichna vzaiemodiia: teoretychni osnovy psykholohichnoho analizu [Pedagogical interaction: theoretical foundations of psychological analysis]. Odesa: PNTs APN Ukrainy [in Ukrainian]

5. Zavadenko, N.N. (2005). Giperaktivnost $i$ defitsit vnimaniya $v$ detskom vozraste : uchebnoe posobie [Hyperactivity and attention deficit in childhood: a textbook]. Moscow : Akademiya [in Russian].

6. Koren, E.V., \& Kupriyanova, E.V. (2015). Giperkineticheskie rasstroystva (SDVG) [Hyperkinetic disorders (SDVG)]. Moscow. Retrieved from https://docplayer.ru/28075910Giperkineticheskie-rasstroystva-sdvg-koren-e-v-kupriyanova-t-a.html [in Russian].

7. Nodelson, S.E. (2018). SDVG. Sindrom defitsita vnimaniya i giperaktivnosti. Semeynaya bolezn [ADHD. Attention deficit hyperactivity disorder. Family illness.]. Samara : Izdatelskiy Dom «Bahra-M» [in Russian].

8. Romanchuk, O. (2005). Hiperaktyvnyi rozlad $z$ defitsytom uvahy u ditei [Hyperactive disorder with attention deficit in children]. Lviv : Svichado [in Ukrainian]

9. Semakova, E.V., \& Makarova, I.Yu. (2005). Semeyno-sotsialnyie usloviya razvitiya giperaktivnosti [Family and social conditions of development of hyperactivity]. Uspehi sovremennogo estestvoznaniya - The successes of modern natural science, 9, 23-26. Retrieved from http://www.natural-sciences.ru/ru/article/view?id=11467 [in Russian].

10. Sukovskyi, Ye. (2008). Hiperaktyvnyi rozlad z defitsytom uvahy u ditei: poradnyk dlia batkiv [Attention Deficit Hyperactive Disorder in Children: A Parental Advisor]. Lviv : Koleso [in Ukrainian]

11. Sukhina, I.V. (2018). Hiperaktyvna dytyna [Hyperactive baby]. Kharkiv : Vyd-vo «Ranok», $\mathrm{VH}$ «Kenhuru». (Inkliuzyvne navchannia) [in Ukrainian]

12. Attention-Deficit / Hyperactivity Disorder. (2013). Diagnostic and Statistical Manual of Mental Disorders (DSM-5) (5 ed.). Arlington, VA: American Psychiatric Publishing. https://doi.org/10.1176/appi.books.9780890425596

13. Anastopoulos, A.D., Sommer, J.L., \& Schatz, N.K. (2009). ADHD and family functioning. Current Attention Disorders Reports, 1, 167-170. https://doi.org/10.1007/s12618-009$\underline{0023-2}$

14. Gozal, D. \& Molfese, D.L. (2005). (Ed.). Attention deficit hyperactivity disorder: from genes to patients. Totowa, New Jersey : Humana Press Inc.

15. Barkley, R.A. (2005). Attention-deficit hyperactivity disorder: A handbook for diagnosis and treatment (3rd. ed.). New York : Guilford Press.

16. Barkley, R.A. (1997). Behavioral Inhibition, Sustained Attention, and Executive Functions: Constructing a Unifying Theory of ADHD. Psychological Bulletin, 121(1), 65-94. https://doi.org/10.1037/0033-2909.121.1.65

17. Barkley, R.A. (2000). Genetics of Childhood Disorders: XVII. ADHD, Part 1: The Executive Functions and ADHD. Journal of the American Academy of Child and Adolescent Psychiatry. 39(8), 1064-1068. https://doi.org/10.1097/00004583-200008000-00025

18. Buhrmester, D., Camparo, L., Christensen, A., Gonzalez, L.S., \& Hinshaw, S.P. (1992). Mothers and fathers interacting in dyads and triads with normal and hyperactive sons. Developmental Psycholy, 28, 500-509. https://psycnet.apa.org/doi/10.1037/0012$\underline{1649.28 .3 .500}$ 
19. Chen, M., \& Johnston, C. (2007). Maternal inattention and impulsivity, and parenting behaviors. Journal of Clinical Child and Adolescent Psychology, Jul-Sep, 36(3), 455-468. https://doi.org/10.1080/15374410701448570.

20. Chronis, A.M., Lahey, B.B., Pelham, W.E., Williams, S.H., Baumann, B.L., Kipp, H., et al. (2007). Maternal depression and early positive parenting predict future conduct problems in young children with attention-deficit/hyperactivity disorder. Developmental Psychology, 43, 70-82. https://doi.org/10.1037/0012-1649.43.1.70

21. Gizer, I.R., Waldman, I.D., Abramowitz, A., Barr, C.L., Feng, Y., Wigg, K.G., \& Rowe, D.C. (2008). Relations between multi-informant assessments of ADHD symptoms, DAT1,

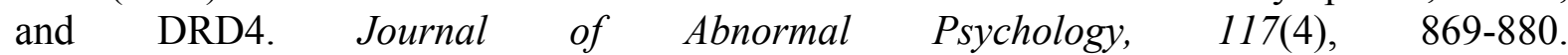
https://doi.org/10.1037/a0013297

22. Godinez, D.A., Willcutt, E.G., Burgess, G.C., Depue, B.E., Andrews-Hanna, J.R., \& Banich, M.T. (2015). Familial risk and ADHD-specific neural activity revealed by a case-control, discordant twin pair design. Psychiatry Research, 233, 458-465. https://dx.doi.org/10.1016\%2Fj.pscychresns.2015.07.019

23. ICD-11 for Mortality and Morbidity Statistics (Version: 04/2019). Retrieved from https://icd.who.int/browse11/1-m/en/\#/http://id.who.int/icd/entity/821852937

24. Johnston, C., \& Mash, E.J. (2001). Families of children with attention-deficit/hyperactivity disorder: Review and recommendations for future research. Clinical Child and Family Psychology Review, 4, 183-207. https://doi.org/10.1023/a:1017592030434

25. Johnston, C., Murray, C., Hinshaw, S.P., Pelham, W.E., \& Hoza, B. (2002). Responsiveness in interactions of mothers and sons with ADHD: Relations to maternal and child characteristics. Journal of Abnormal Child Psychology, 30(1), 77-88. https://doi.org/10.1023/a:1014235200174

26. Johnston, Ch. \& Jassy, J. (2007). Attention-Deficit/Hyperactivity Disorder and Oppositional/Conduct Problems: Links to Parent-Child Interactions. Journal of the Canadian Academy of Child and Adolescent Psychiatry, May, 16(2), 74-79. Retrieved from https://www.ncbi.nlm.nih.gov/pmc/articles/PMC2242643/

27. Nigg, J.T., Stavro, G., Ettenhofer, M., Hambrick, D.Z., Miller, T., \& Henderson, J.M. (2005). Executive Functions and ADHD in Adults: Evidence for Selective Effects on ADHD. Journal of Abnormal Psychology, Nov; 114(4), 706-717. https://doi.org/10.1037/0021$\underline{843 X .114 .3 .706}$

28. Solanto, M.V. (2002). Dopamine dysfunction in AD/HD: integrating clinical and basic neuroscience research. Behavioural Brain Research, Mar, 10; 130(1-2), 65-71. https://doi.org/10.1016/s0166-4328(01)00431-4

29. Tuckman, A. (2009). More Attention, Less Deficit: Success Strategies for Adults with ADHD. Plantation, Florida; Specialty Press.

30. Willcutt, E. (2005). The Etiology of ADHD: Behavioral and Molecular Genetic Approaches. Barch, D. (Ed.). Cognitive and Affective Neuroscience of Psychopathology. Oxford : Oxford University Press.

Retrieved from https://pdfs.semanticscholar.org/3bb9/88b02a9829367286995a1fc837440bb4719f.pdf

31. Willcutt, E.G., Pennington, B.F., Duncan, L., Smith, S.D., Keenan, J.M., Wadsworth, S.J., DeFries, J.C., \& Olson, R.K. (2010). Understanding the complex etiologies of developmental disorders: behavioral and molecular genetic approaches. Journal of Developmental and Behavioral Pediatrics, 31(7), 533-544. https://doi.org/10.1097/DBP.0b013e3181ef42a1

32. Zisser, A.R. \& Eyberg, Sh.M. (2012). Maternal ADHD: Parent-Child Interactions and Relations With Child Disruptive Behavior. Child \& Family Behavior Therapy, 34(1), 33-52. Https://doi.org/10.1080/07317107.2012.654450 


\title{
PECULIARITIES OF THE INTERACTION OF PARENTS AND CHILDREN WITH ATTENTION DEFICIT HYPERACTIVITY DISORDER Natalia Goncharenko \\ Postgraduate student of the Department of Psychology \\ National Pedagogical Drahomanov University \\ 9, Pyrohov Str., Kyiv, Ukraine, 01601 \\ practical psychologist \\ Children Clinical hospital \# 4, Solomjanski district \\ 3, Komarov avenue, Kyiv, Ukraine, 03680 \\ n.a.honcharenko@gmail.com, http://orcid.org/0000-0001-5386-3772
}

\begin{abstract}
The article raises an urgent question of the characteristics of the interaction of parents and children with a diagnosis of ADHD - attention deficit hyperactivity disorder. It is noted that despite an increase in scientific knowledge about the genetic and neuropsychological mechanisms of the appearance and development of the syndrome, the quality level of education and the skills of effective interaction between parents and teachers with such children is remained quite low. Today, attention deficit hyperactivity disorder is a recognized by medical science as a disease of neuropsychological etiogenesis due to a complex combination of hereditary and socio-psychological factors, none of which is necessary or sufficient to cause the development of ADHD in itself. The importance of adaptive parenting of a child with ADHD in the family to optimize his/her development and reduce the likelihood of negative symptoms accompanying the disorder is considered obvious.
\end{abstract}

Risk factors for children with ADHD in the future to have such adverse effects as substance abuse, crime, aggressiveness, and opposition behavior are maternal depression, excessive directiveness and exactingness. Pathological conditions for children with ADHD are conditions of structural blurring of the family, diffuseness in accepting roles, educational insecurity of parents, and lack of reflection on educational interaction.

Empirical data show that more appropriate models of interaction with a child are characteristic of complete families, parents of more mature age with higher education. In such families there is a greater response of parents to working with a psychological service to help the child adaptively socialize and prevent the negative consequences of the disorder. Most ineffective models impatience, backward aggression, punishment, despair, fruitless persuasion - are used in interaction with children by young mothers (who gave birth to children under 18), some parents. The worst situation with the uncontrolled behavior of a child at home and at school is observed in dysfunctional families, where there are conflicts, quarrels, father's drunkenness, coldness, detachment of the mother, and those with tight housing and material conditions of the family.

It is concluded that although family education cannot cause the appearance of ADHD symptoms in children (biological factors are responsible for their appearance), the ability of parents to interact with them effectively helps to prevent the development of problematic opposition behavior and addictions in children in the future. ADHD education and helping parents to learn effective educational strategies for their interactions with their children can offset the negative effects on children. Psychological and psychiatric help for mothers who have their own problems associated with ADHD (impulsiveness, impatience, excessive anxiety, a tendency to depression, emotional imbalance, etc.) and high stress levels can also become a significant factor in improving the structure of family interaction in the parent-child system.

Keywords: attention deficit hyperactivity disorder, nervous system development disorders, control functions, executive functions, neurobiological mechanisms, interaction of parents and children.

Подано 09.12.2019

Рекомендовано до друку 18.12.2019 